\title{
The Good and Bad of Ambidexterity: In Which Domains Should Firms Be Ambidextrous or Not to Foster Innovativeness?
}

\author{
Nicolas A. Zacharias \\ Technische Universität Darmstadt \\ zacharias@,bwl.tu-darmstadt.de
}

\begin{abstract}
Because it is difficult and costly for firms to practice exploration and exploitation simultaneously in their new product development, managers need to know when investing in ambidexterity is beneficial for their firm's innovativeness and when it is not. To date, research has remained undecided about the performance implications of striving for the joint implementation of exploration and exploitation. To address this persistent debate, the current study develops a new conceptualization that distinguishes two forms of ambidexterity, with contrasting effects on innovativeness. Drawing on dynamic capabilities theory, this study proposes that market-based ambidexterity benefits companies' innovativeness, whereas product-based ambidexterity harms it. The empirical results, obtained from longitudinal data gathered from 229 executives in multiple industries, confirm these theorized effects of the two forms of ambidexterity on product program innovativeness, which in turn increases firm performance. These findings help explain the varying effects of ambidexterity in prior research and offer important managerial and decision-making implications.
\end{abstract}

\section{Introduction}

In competitive market environments, innovative firms seek both to make use of their existing knowledge (exploitation) and to create new knowledge (exploration), as a basis for developing new products [1]. Each approach can be promising, and an ability to implement exploration and exploitation simultaneously (ambidexterity) may be particularly advantageous for product innovation activities [2, 3, 4]. However, for various reasons, firms often find it difficult and costly to engage in exploration and exploitation at the same time. Therefore, managers need clear insights into when it might benefit their firms' innovativeness to make their innovation activities ambidextrous — as well as when they should focus on either exploitation or exploration.

In some settings, exploration and exploitation combine beneficially, but in others, they cannot be brought together effectively, so focusing on one or the other yields more benefits. The challenge for managers is finding a way to identify when the simultaneous combination of explorative and exploitative innovation is more likely to lead to success, or when it is preferable to focus on just one route.

From an academic perspective, extant literature offers equivocal findings about ambidexterity in product innovation contexts $[5,6]$. Some scholars cite its benefits [7, 8, 9]; others emphasize its negative effects $[10,11]$. Overall, "empirical evidence of the organizational ambidexterity-performance relationship remains limited and mixed" [12, p. 393] and information systems research has called for deeper investigations of the phenomenon [13]. In particular, new insights regarding the performance implications of a joint implementation of exploration and exploitation in new product development are necessary [11, 14].

The mixed results in prior research also suggest the need to refine the concept of ambidexterity. Relevant research streams, such as those pertaining to organizational adaptation and design [9] or strategic management [15], differentiate ambidexterity in product versus market domains. Product innovations may correspond to the product domain, such that they extend a firm's existing product portfolio with a new variant, or they could involve the market domain, such that they move the firm into new or different markets [9]. From this view, a more sophisticated distinction of the different domains of product innovation, and thus the different forms of ambidexterity, may be worthwhile for both research and practice. Therefore, we develop and test a new conceptualization of ambidexterity for product innovation to investigate a central research question: In which domains should firms be ambidextrous or not in their product innovation activities to foster innovativeness? In answering this question, we offer a twofold contribution. 
First, a revised understanding of ambidexterity, based on the distinction of its two different forms, may help managers ensure that their firm's products are innovative. Exploration generally leads to radical new products; exploitation tends to foster incremental innovations that meet the needs of existing customers or markets $[16,17]$. Incremental innovations added to an existing product portfolio may be just as valuable as more substantial innovations that extend the portfolio or move the firm into different markets $[18,9]$, so managers usually strive to include both. However, it is difficult to balance exploration and exploitation in the effort to implement effective innovation management [19]; this study sheds light on the managerial challenge by specifying the domains in which exploration and exploitation work well together as complements, as well as domains in which ambidexterity is detrimental to firms' innovativeness.

Second, a more sophisticated conceptualization of the ambidexterity phenomenon allows for a more indepth investigation of its performance implications. For researchers, an important question pertains to the innovativeness consequences that arise, depending on the form of ambidexterity. Specifically, we analyze the impact of two types of ambidexterity on product program innovativeness, which we define as the degree of difference between a company's product program and existing alternatives [20], which in turn affects firm performance. Thus this study clarifies the mechanism that links different forms of ambidexterity to innovativeness, and then to firm performance. Drawing on dynamic capabilities theory [19, 21], we propose that product- and market-based ambidexterity have varying effects, depending on the complementarity of their underlying phenomena. By differentiating these two forms, we affirm a positive impact of ambidexterity [7] and also support prior research that suggests some potentially detrimental tensions resulting from ambidexterity [10]. That is, this study contributes to the ongoing discussion about whether ambidexterity is beneficial or not $[10,22]$.

\section{Theoretical development and hypotheses 2.1. Two forms of ambidexterity}

Starting with March's work on exploration and exploitation in organizational learning [23], researchers have developed various conceptualizations of exploitation and exploration in contexts related to organizational adaptation and design [24, 25, 26, 27], strategic management $[15,28,29]$, and innovation management [1, 11, 14]. Many conceptualizations confound different domains, such that a more differentiated conceptualization might enhance our understanding of the ambidexterity phenomenon and provide a firmer theoretical foundation.

Several conceptual arguments indicate the need for a clearer distinction between the product and market domains of product innovation. First, innovations that represent these two domains are conceptually distinct, in terms of their proximity to existing technologies, goods, and services, as well as to existing customer or market segments [30, 17]. Second, innovation in the product domain requires different skills and know-how than product innovation in the market domain [16]. For example, engineering and manufacturing know-how likely are necessary for the former, but the latter specifically requires knowledge of customer needs and distribution and sales channels [31]. Third, in relation to two basic business functions, research and development (R\&D) and marketing, product and market development represent distinct perspectives on innovation [9, 15]. Ansoff established the distinction between these two domains in a growth framework, published more than 50 years ago [32].

The distinction also receives support from an empirical perspective. The operationalizations of exploration in extant literature reveal two notable concerns. First, most scales that measure exploration combine the product and market domains in their items $[17,33,34]$. Second, many well-established exploration scales appear in shortened forms [e.g., 34], implying that researchers have eliminated some indicators to achieve higher construct reliability and validity. Thus the concept of exploration-and of ambidexterity-appears more complicated than generally believed, and different forms may be confounded in existing conceptualizations.

To derive a more sophisticated ambidexterity approach, differentiated for product and market domains, we turn to the underlying phenomena of exploitation and exploration. Exploitation is clearly defined: It is the pursuit of innovations that build on existing knowledge and extend existing products for existing customers [17]. Thus, companies expand neither their product nor their market domain, beyond what they already know. Any further distinction between multiple domains of exploitation is unnecessary.

In contrast, for exploration the domain of development is not as clearly demarcated, and the definition is not as well established. Drawing on various conceptual and empirical arguments, we seek to distinguish between product- and market-based exploration. On the basis of prior literature, we define product-based exploration as the pursuit of new knowledge implemented in the development of new products [17]. Consistently, market-based exploration refers to the pursuit of new knowledge that will be 
used to create new opportunities for new customers or markets. Figure 1 summarizes this new, extended conceptualization of exploration. Similar to Ansoff's matrix of growth strategies [32], our conceptualization distinguishes between product and market development. The upper right part represents a classic conceptualization of exploration; the lower left part refers to exploitation with no product or market development. The upper left and lower right parts of the matrix (i.e., product-based and market-based exploration) have not been addressed explicitly by prior ambidexterity research and are new to the field.

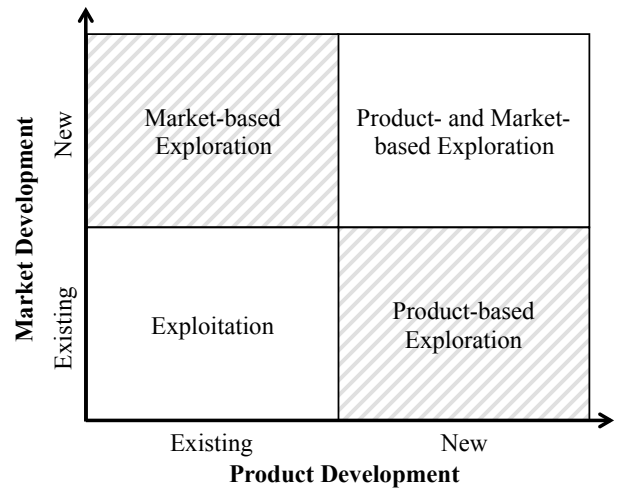

Figure 1. New conceptualization of exploration

Because ambidexterity entails the ability to balance exploration and exploitation simultaneously in a tradeoff $[3,15]$, we propose two different forms, resulting from the two forms of exploration in combination with exploitation. Accordingly, we define product-based ambidexterity as the ability to balance product-based exploration with exploitation, whereas market-based ambidexterity is the ability to balance market-based exploration with exploitation.

Information systems research on ambidexterity has not touched on this distinction [8, 35]. A few existing studies address the two different domains but appear in the organizational adaptation or strategic management fields; they concur that the product domain and the market domain should be treated as distinct. For example, Voss and Voss take a strategic view of ambidexterity by small and medium-sized enterprises and find varying effects of different forms of ambidexterity on revenues [15]. Tushman et al. demarcate the target market and technological change and show that these dimensions are independent [9]. These results, indicating the differential effects of ambidexterity in product and market domains, suggest that the newly developed concepts of product-based and market-based ambidexterity may represent distinct dimensions in the context of product innovation.

\subsection{Dynamic capabilities theory}

Drawing on dynamic capabilities theory [19, 21], this study predicts how two forms of ambidexterity relate uniquely to innovativeness. Dynamic capabilities, which can be defined as “a firm's ability to integrate, build, and reconfigure internal and external competencies to address rapidly changing environments" [21, p. 516], serve to reallocate organizational assets and competencies, both internal and external [26]. Effective product innovation requires complementary competencies to achieve this sort of cross-fertilization $[21,26]$.

From this perspective, ambidexterity is a dynamic capability that enables firms to sense and make use of new (product and market) opportunities by reconfiguring their competencies [19, 26, 34]. Both product-based exploration and exploitation are associated with R\&D activities, so they represent internal competencies. In contrast, market-based exploration is an external competency, due its focus on markets and customers. The ambidexterity dynamic capability helps balance the joint implementation of these multiple competencies.

Traditionally, extant literature has assumed a positive effect of dynamic capabilities on performance; however, researchers have started to disagree about this assessment, positing that in some situations, the benefits cannot be realized [36]. For example, an internal competency may complement an external one [37], but this balance may be more challenging or even impossible for the combination of multiple internal or external competencies, because they do not complement one another well. Extant literature also indicates that factors leading to dynamic capabilities require a particular match, such that they must complement one another well [38]. We develop the theoretical mechanisms for our hypotheses with these considerations in mind.

\subsection{Study framework}

The framework in Figure 2 depicts product-based exploration, market-based exploration, and exploitation as independent variables that influence product program innovativeness. The center of the framework encompasses the two forms of ambidexterity, representing combinations of each of the two forms of exploration with exploitation, that is, product-based and market-based ambidexterity. This demarcation may offer new insights into the important trade-off decisions that are required across different forms of exploration and exploitation in companies.

Our investigation is at the company level, and our outcomes reflect this level too. That is, we assess product program innovativeness, or the degree of 
difference between a company's product program and existing alternatives [20], which represents an appropriate outcome for product innovations that result from both product-based and market-based ambidexterity. In the last step in the causal chain, product program innovativeness influences firm performance, as detailed in the next section.

\subsection{Hypotheses}

Drawing on extant research, we anticipate that product- and market-based exploration both positively affect product program innovativeness. From a theoretical perspective, product innovations resulting from exploration tend to be radical, regardless of whether they offer new designs or new functionalities or rely on new distribution channels, target new customers, and create new markets $[17,30]$. Therefore, product- and market-based forms of exploration both should offer valid pathways for companies to increase their product program innovativeness by creating radical innovations that are novel to customers. In addition, many empirical studies support the positive effects of exploration on innovativeness $[7,11]$.

Exploitation should positively affect product program innovativeness as well. Whereas exploration leads to innovation through radical new products, exploitation fosters incremental innovations that meet the needs of existing customers or markets [16, 17]. Product innovations based on exploitation broaden existing knowledge and skills, improve existing products, and increase the efficiency of extant distribution channels and market segments [17]. Therefore, exploitation should foster companies' product program innovativeness by creating incremental innovations that also are novel to customers, though to a lesser degree. Extant empirical findings affirm a positive effect of exploitation on innovativeness $[7,11]$.

The performance implications of ambidexterity are particularly important for companies seeking to align their exploration and exploitation [14]. A one-sided focus on either exploration or exploitation may lead to vicious cycles that produce conventional mindsets and routines $[10,3]$; balancing them, in the form of product- and market-based ambidexterity, should be key to innovative success. Firms that explore at the expense of exploitation may incur considerable costs without harvesting any benefits [1]; firms that exploit without exploration may miss technological progress or changes in customer preferences $[1,39]$.

However, current research leaves unclear whether the combination of exploration and exploitation is beneficial and in which conditions [7, 40]. Drawing on dynamic capabilities theory, this study proposes that the complementarity or non-complementarity of competencies constitutes a theoretical mechanism for explaining the differential effects of product- and market-based ambidexterity on product program innovativeness. Effective innovation management requires complementary competences $[21,26]$.

We thus propose that product-based exploration and exploitation in combination lead to tensions, because they are less complementary. Both are internal competencies that rely on the firm's own R\&D activities, which also aim to foster product program innovativeness [7]. Although each internal competency fosters product program innovativeness in general, when pursued in combination, they lead firms to adopt an overly strong inward focus in their product innovation activities. Product-based exploration and exploitation both target existing customers and markets, so firms with both competencies likely lose sight of emerging customers and markets and become less innovative. Ultimately, product-based ambidexterity may be detrimental to product innovativeness, so we hypothesize:

H1: Product-based ambidexterity negatively affects product program innovativeness.

In contrast, the competencies associated with market-based ambidexterity differ in nature, such that market-based exploration and exploitation should be complementary and reinforce the other's beneficial effects [41]. Market-based exploration is an external competency, due to its focus on markets and customers, and it relies on market intelligence and marketing programs that aim to attract new customers and seize market opportunities [15]. In this sense, it is strongly complementary with an internal exploitation competency. Knowledge about customers and markets, combined with the ability to improve existing products and service, likely results in innovative products for new customers and markets. Thus, the two competencies cross-fertilize and complement each other, because they unite an internal with an external competency to produce market-based ambidexterity. Combining market-based exploration and exploitation eventually should result in an innovative product program, and we propose:

H2: Market-based ambidexterity positively affects product program innovativeness.

The relationship of product program innovativeness with firm performance represents the last stage of our model. This link has been well discussed in extant literature; scholars argue that an innovative product program improves market shares, market value, growth, and survival rates [42, 43, 44]. These findings indicate that product program innovativeness 
represents a competitive advantage, prompting superior firm performance. Accordingly, we hypothesize:

H3: Product program innovativeness positively affects firm performance.

\section{Methods}

\subsection{Sample, data collection and measures}

This study relies on longitudinal data, obtained from participants of an international executive MBA program. We started the data collection by sending emails to 298 executives who attended the program and asking for their participation in a survey study pertaining to strategy and innovation. Each executive received a written questionnaire to complete. After a follow-up e-mail, the sample included 229 executives (response rate $=76.9 \%$ ), but the effective sample size decreased to 221 executives for the structural equation modeling (SEM) analysis, due to missing data. To increase confidence in the generalizability of the findings and prevent potential bias due to industry characteristics, we collected data from respondents representing diverse industry sectors: The participating executives held $\mathrm{C}$-level positions or profit-and-loss responsibility in a wide range of industries, including manufacturing $(24.9 \%)$, professional services $(21.7 \%)$, IT $(19.0 \%)$, banking $(12.2 \%)$, retail and fast moving consumer goods (10.4\%), machinery and electronics (6.4\%), and utilities (5.4\%). The sample also covered a wide range of firm sizes, with annual sales ranging from less than US\$5 million to more than US\$1 billion. The respondents' mean age was 39 years.

In a second step, we collected data for the dependent variable one year later. This time-lagged measurement increased confidence in our causal inferences about the relationship between product program innovativeness and firm performance. In particular, it acknowledged that innovative products may not translate instantaneously into improved firm performance. At time 2, we obtained data from 155 of the 229 executives who responded at time 1 .

To operationalize the independent, dependent, and control variables, we used existing measurement scales. All constructs were measured with multipleitem, seven-point Likert-type scales $(1=$ "strongly disagree" and $7=$ "strongly agree"). The items for all main constructs, including the sources of the measurement scales, appear in Table 1.

\section{Table 1. Scale items for the main constructs}

Product-Based Exploration (based on [17])

We invent new products and services.

We experiment with new products and services in our local market.
We commercialize products and services that are completely new to our company.

Market-Based Exploration (based on [17])

We frequently utilize new opportunities in new markets. Our company regularly uses new distribution channels. We regularly search for and approach new clients in new markets.

Exploitation (based on [17]))

We frequently refine the provision of existing products and services.

We regularly implement small adaptations to existing products and services.

We introduce improved versions of existing products and services for our local market.

We improve our provision efficiency of products and services.

Product Program Innovativeness (based on [20])

The products/services of our company...

....are novel.

....are inventive.

...differ significantly in terms of their newness from existing products/services of competitors.

....are exceptional.

Firm Performance (adapted from [45])

To what extent has your company achieved better results than the competition in these areas in the last year?

Overall performance

Profitability

Sales

Return on investments

Return on sales

For product-based and market-based exploration, we split up the well-established scale provided by Jansen et al. [17] and confirmed our operationalization in an exploratory factor analysis. Specifically, when the number of extracted factors was not predetermined and all indicators of the two constructs were allowed to load on any of the extracted factors, the analysis indicated that product- and market-based exploration existed as proposed, and the indicators loaded only on their respective factors.

To operationalize product- and market-based ambidexterity, we created multiplicative interaction terms of product-based exploration and market-based exploration, respectively, with exploitation [3, 7]. Among the various options for operationalizing ambidexterity (for an overview, see [33]), a multiplicative interaction of exploration and exploitation can capture the phenomenon well [22].

Furthermore, we included firm size and three industry-related environmental variables - competitive intensity [46], technological turbulence [46], and industry sector-as control variables in our model. Previous studies related to innovation management suggest controlling for these environmental factors, because product innovation success depends on the 
relative influence of market forces that companies encounter [47, 48].

We used exploratory and confirmatory factor analyses to test the reliability and validity of the reflective multi-item measures. For all constructs, the Cronbach's alpha values clearly exceeded the recommended minimum of .7, signifying a high degree of internal consistency among the corresponding indicators. In addition, composite reliability was greater than the threshold value of .6 for all constructs [49]. All factor loadings also were significant at $p<$ .01 . These results suggest the strong convergent validity of our constructs [49].

We performed two tests of discriminant validity. First, the chi-square difference tests for each pair of constructs yielded significant values, well above the recommended minimum of 3.84 at $p<.05$ [50]. Second, we applied Fornell and Larcker's rigorous criterion [51]. For each pair of constructs, the square roots of the average variances were greater than their respective correlation, indicating that discriminant validity was not a problem in our study.

\subsection{Hypotheses testing procedure for the study framework}

To test our hypotheses, we applied SEM with latent interactions in MPLUS 7 [52]. To leverage the maximum variance of the model, particularly for investigating the relationships between the two forms of ambidexterity and innovativeness, we incorporated lagged firm performance by simultaneously estimating the missing values, using maximum likelihood imputation. We did not find a reason for systematic non-response one year later, suggesting that this procedure is suitable. The analytical procedure followed a logic similar to that underlying the hierarchical moderated regression analysis. In the first step, we ran an initial model that included all basic effects and control variables. In a second step, we ran another model that also included the latent interaction terms to test the ambidexterity hypotheses. To test for interaction effects, we included the latent interactions in our SEM. After mean-centering all the indicators [53], we specified the interaction terms by multiplying the item values of the two corresponding constructs, which produces highly reliable results [54]. The model for the interaction effects includes all effects from the basic model together with the interaction terms, and the entire model was run simultaneously.

To check for common method bias, we conducted three tests. In addition to Harman's single-factor test, we ran a marker variable test [55], using firm size as the marker variable, because it theoretically should be uncorrelated with our dependent variables. All correlations remained significant after controlling for the marker variable's effect. Finally, we included a common method factor in our structural model. All the items for the constructs in our basic model were allowed to load on this factor, which was uncorrelated with the other constructs. An inspection of the path coefficients in the resulting model revealed that the effects in our model held, even when we included this common method factor. Altogether, the findings of the three tests offered a strong indication that common method bias did not influence our results or pose a problem for our study.

\section{Results}

Following the previously described procedure, we used SEM to test the study framework-and $\mathrm{H}_{1}, \mathrm{H}_{2}$, and $\mathrm{H}_{3}$ in particular. The model showed satisfactory global fit measures $\left(\mathrm{N}=221 ; \chi^{2} / \mathrm{df}=2.015\right.$; root mean square error of approximation $=.068$; square root mean residual $=.076$ ). The standardized path coefficients and their significance levels appear in Figure 2.

Regarding the direct effects of the two forms of exploration on product program innovativeness, we found a positive effect of product-based exploration $(.49, p<.01)$, whereas market-based exploration had a non-significant effect on the dependent variable (-.04, n.s.). Furthermore, exploitation showed a positive relationship with product program innovativeness (.21, $p<.05)$. Thus, product-based exploration and exploitation both can exert positive influences and enable innovative products.

We proposed a negative relationship in $\mathrm{H}_{1}$ between product-based ambidexterity and product program innovativeness. This hypothesis was supported by a negative effect $(-.27, p<.05)$. Although product-based exploration and exploitation were beneficial individually, they exerted a detrimental influence when combined in the form of product-based ambidexterity.

Market-based ambidexterity should have a positive effect on product program innovativeness, according to $\mathrm{H}_{2}$. The empirical results confirmed this effect (.47, $p<.01)$; market-based ambidexterity enabled innovativeness. Whereas on its own, market-based exploration exerted no statistically significant influence, market-based ambidexterity can support companies striving to generate innovative product programs.

To complete the causal chain, we determined that product program innovativeness had a significant, positive impact on firm performance $(.32, p<.01)$ at time 2. Thus, we found support for $\mathrm{H}_{3}$, in that ambidexterity in a product innovation context eventually affects more downstream outcomes. 
Among the control variables, we found only minimal influences. Competitive intensity exerted a negative influence on product program innovativeness $(-.15, p<.05)$, and technological turbulence had a positive effect on the same variable $(.17, p<.01)$. The linkages of competitive intensity and technological turbulence to firm performance were not significant though. Nor were the paths related to firm size and industry sectors significant, except that the IT industry exerted a negative effect on product program innovativeness $(-.18, p<.01)$. well. The complementarity or non-complementarity of the underlying competencies affect the performance outcomes of the distinct forms of ambidexterity and determine the organizational interplay of the two forms of exploration with exploitation [38]. Specifically, product-based ambidexterity leads to tensions, because firms adopt an overly inward focus in their product innovation activities and lose sight of emerging customers or markets. In contrast, market-based ambidexterity exerts a positive effect on

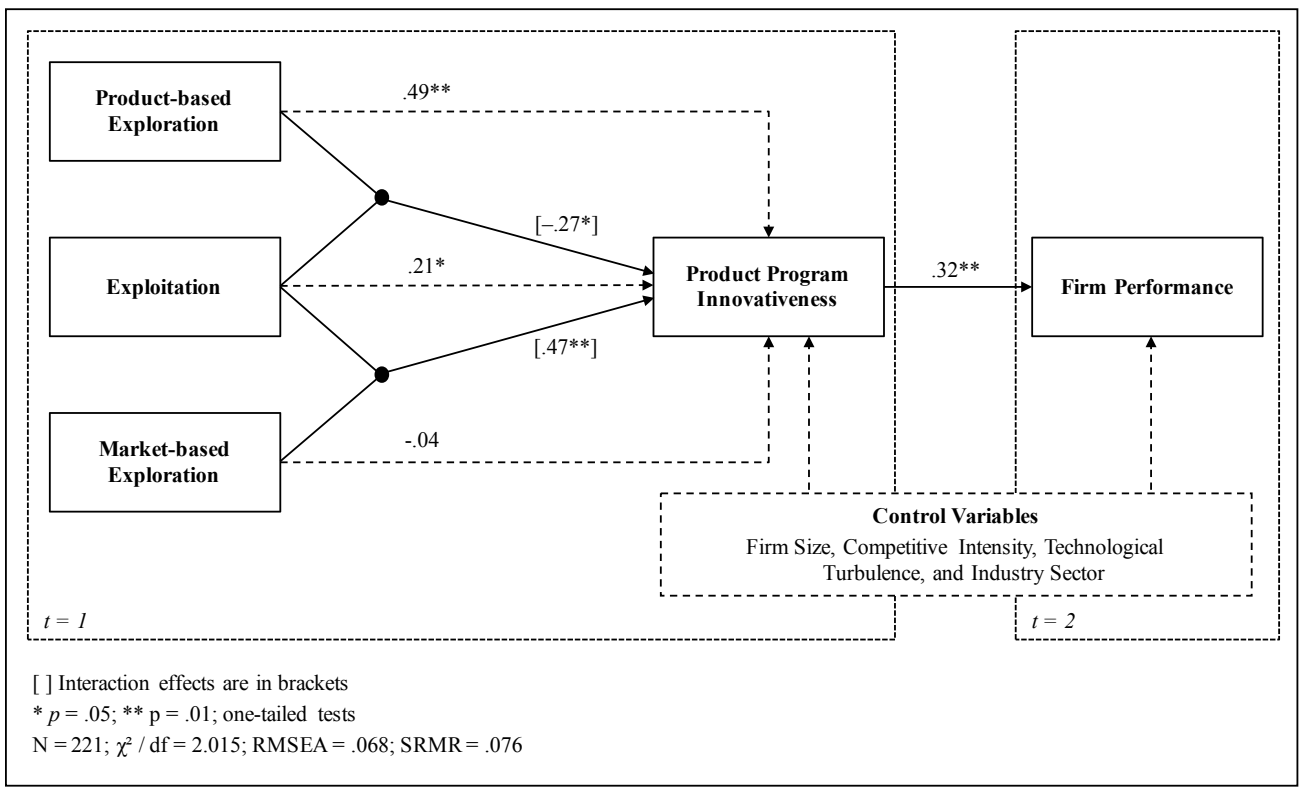

Figure 2. Study framework and SEM results

\section{Discussion}

\subsection{Research implications}

This study extends research on the combination of exploratory and exploitative innovation by proposing and confirming a more sophisticated conceptualization of ambidexterity. Extant research has focused strongly on the antecedents [34] and outcomes [3] of ambidexterity. This study aims to understand the phenomenon itself in greater detail. Adding to the latest research in information systems [35, 56] and building on recent work in adjacent research streams $[9,15]$, we propose a conceptual distinction between product- and market-based ambidexterity to capture the content focus more specifically and extend the theoretical breadth pertaining to this phenomenon.

Drawing on dynamic capabilities theory [19, 21], we also explain how the two forms of ambidexterity relate differently to product program innovativeness and subsequent firm performance. The dynamic capability of ambidexterity can be ambidextrous as innovativeness. Its underlying competencies are complementary, in that they combine inward and outward perspectives, each reinforcing the beneficial effect of the other [41]. With this study, we follow the path of recent research [36] that has started to disagree with the widespread assumption that dynamic capabilities are generally positive and that in some settings, the expected benefits cannot be realized.

Furthermore, this study contributes to the ongoing discussion about whether and to what degree ambidexterity is beneficial $[10,22]$. Ambidexterity can influence innovativeness in both positive and negative directions, depending on its focus on products or markets. This study thereby reconciles the positions of scholars who advocate for the positive effects of ambidexterity [3, 22] with those who highlight its potential negative effects $[10,11]$. This insight can help the debate move to a more detailed level and produce further insights for the field.

\subsection{Managerial implications}


To shape the fate of their companies, managers need to distinguish not only between exploratory and exploitative innovation but also product-based and market-based ambidexterity. Then they can match an appropriate innovation strategy and a corresponding implementation in their firms' innovation endeavors. Depending on the overarching goals, firms may need to acquire and retain specific competencies. Productbased exploration requires a strong focus on core R\&D activities, paired with the generation of new knowledge; market-based exploration can be fostered by extensive market research that delivers important inputs regarding the needs of new customers or markets. Finally, exploitation requires very good knowledge of and strong relationships with existing customers. The distinctions among these competencies likely relate to structures and processes, and then also influence which resources are necessary and which incentives are optimal for producing them.

To achieve effective innovation management, this study suggests two pathways that should lead to innovative product programs and firm performance. First, managers could focus on either product-based exploration or exploitation, to avoid the negative effects of product-based ambidexterity. Such efforts should prevent the detrimental consequences of organizational tensions that result from an overly strong inward focus in their product innovation activities. To follow this pathway, the focus on either product-based exploration or exploitation should be clear. Second, managers who want to implement ambidexterity in the context of product innovation should stay in the market domain. By relying on market-based exploration and exploitation, firms combine internal and external competencies, which cross-fertilize each other and benefit innovation activities. Fostering market-based ambidexterity seems most promising as a means to achieve beneficial effects for product program innovativeness.

In addition, the results suggest that market-based exploration on its own is ineffective; rather, it becomes effective only in combination with exploitation, when it constitutes market-based ambidexterity. This finding implies that slightly improved products are best suited to address the preferences of new customers or markets, even if these improvements initially target existing customers. Companies may be particularly successful if they introduce products to new customers and/or markets, adapted to the specific circumstances of their target segments.

\subsection{Limitations and avenues for research}

Although this study provides several important contributions, it also contains limitations that suggest avenues for further research. First, we focused on exploration, exploitation, and ambidexterity in a product innovation context $[1,14]$. Further research should investigate whether the proposed new conceptualizations of exploration and ambidexterity, as well as their performance outcomes, also hold in other areas, such as organizational adaptation and design or strategic management. Such investigations could offer an even more sophisticated understanding of the ambidexterity phenomenon and add theoretical links to these fields.

Second, we consider simultaneous ambidexterity, or the firm's ability to balance exploration and exploitation simultaneously in a concurrent trade-off situation [3, 15]. Extant research also proposes temporal shifting as a way to be ambidextrous, through sequential implementations and switches between exploration and exploitation [26]. Additional studies could investigate the extent to which the results of the present study differ when ambidexterity is conceptualized as the sequential, rather than simultaneous, pursuit of exploration and exploitation.

Third, the data in this study represent two different points in time, but further explorations also might investigate how companies shift among the two forms of exploration, exploitation, and the resulting productbased and market-based ambidexterity over extended periods. Such approaches could offer additional insights into necessary structural and cultural changes, which may serve as implementation guidelines for managerial practice. For such a study, panel data gathered over multiple years would be advisable

\section{References}

[1] F.T. Rothaermel and M.T. Alexandre, "Ambidexterity in technology sourcing: The moderating role of absorptive capacity”, Organization Science (20:4), 2003, pp. 759-780.

[2] C. Andriopoulos and M.W. Lewis, "Managing innovation paradoxes: Ambidexterity lessons from leading product design companies", Long Range Planning (43:1), 2010, pp. 104-122.

[3] C.B. Gibson and J. Birkinshaw, "The antecedents, consequences, and mediating role of organizational ambidexterity", Academy of Management Journal (47:2), 2004, pp. 209-226.

[4] C. Kim, J. Song, and A. Nerkar, "Learning and innovation: Exploitation and exploration trade-offs", Journal of Business Research (65:8), 2012, pp. 1189-1194.

[5] M.L. Tushman and C.A. O'Reilly, "Ambidextrous organizations: Managing evolutionary and revolutionary change", California Management Review (38:4), 1996, pp. 830 . 
[6] M.L. Tushman and W. Smith, "Organizational technology: Technological change, ambidextrous organizations, and organizational evolution", in: J.A.C. Baum (Ed.), The Blackwell companion to organizations (pp. 386-414), London: Blackwell, 2002.

[7] Z.-L. He and P.-K. Wong, "Exploration vs. exploitation: An empirical test of the ambidexterity hypothesis", Organization Science (15:4), 2004, pp. 481-494.

[8] D.E. Leidner, J. Lo, and D. Preston, "An empirical investigation of the relationship of IS strategy with firm performance", Journal of Strategic Information Systems (20), 2011, pp. 419-437.

[9] M.L. Tushman, W.K. Smith, R.C. Wood, G. Westerman, and C.A. O'Reilly, "Organizational designs and innovation streams", Industrial \& Corporate Change (19:5), 2010, pp. $1331-1366$

[10] C. Andriopoulos and M.W. Lewis, "Exploitationexploration tensions and organizational ambidexterity: Managing paradoxes of innovation", Organization Science (20:4), 2009, pp. 696-717.

[11] K. Atuahene-Gima, "Resolving the capability-rigidity paradox in new product innovation", Journal of Marketing (69:4), 2005, pp. 61-83.

[12] S. Raisch and J. Birkinshaw, "Organizational ambidexterity: Antecedents, outcomes, and moderators", Journal of Management (34:3), 2008, pp. 375-409.

[13] E.M. Daniel, J.M. Ward, and A. Franken, "A dynamic capabilities perspective of IS project portfolio management", Journal of Strategic Systems (23), 2014, pp. 95-111.

[14] G.B. Voss, D. Sirdeshmukh, and Z.G. Voss, "The effects of slack resources and environmental threat on product exploration and exploitation", Academy of Management Journal (51:1), 2008, pp. 147-164.

[15] G.B. Voss and Z.G. Voss, "Strategic ambidexterity in small and medium-sized enterprises: Implementing exploration and exploitation in product and market domains", Organization Science (24:5), 2013, pp. 1459-1477.

[16] E. Danneels, "The dynamics of product innovation and firm competences", Strategic Management Journal (23:12), 2002, pp. 1095-1121.

[17] J.J.P. Jansen, F.A. Van Den Bosch, and H.W. Volberda, "Exploratory innovation, exploitative innovation, and performance: Effects of organizational antecedents and environmental moderators", Management Science (52:11), 2006, pp. 1661-1674.

[18] K.M. Eisenhardt and B.N. Tabrizi, "Accelerating adaptive processes: Product innovation in the global computer industry", Administrative Science Quarterly (40:1), 1995, pp. 84-110.

[19] D.J. Teece, "Explicating dynamic capabilities: The nature and microfoundations of (sustainable) enterprise performance", Strategic Management Journal (28:13), 2007, pp. 1319-1350.

[20] R.M. Stock and N.A. Zacharias, "Patterns and performance outcomes of innovation orientation", Journal of the Academy of Marketing Science (39:6), 2011, pp. 870888 .

[21] D.J. Teece, G. Pisano, and A. Shuen, "Dynamic capabilities and strategic management", Strategic Management Journal (18:7), 1997, pp. 509-533.

[22] S. Raisch, J. Birkinshaw, G. Probst, and M.L. Tushman, "Organizational ambidexterity: Balancing exploitation and exploration for sustained performance", Organization Science (20:4), 2009, pp. 685-695.

[23] J.G. March, "Exploration and exploitation in organizational learning", Organization Science (2:1), 1991, pp. 71-87.

[24] S. Auh and B. Menguc, "Balancing exploration and exploitation: The moderating role of competitive intensity", Journal of Business Research (58:12), 2005, pp. 1652-1661.

[25] J.J.P. Jansen, D. Vera, and M. Crossan, "Strategic leadership for exploration and exploitation: The moderating role of environmental dynamism", Leadership Quarterly (20:1), 2009, pp. 5-18.

[26] C.A. O'Reilly and M.L. Tushman, "Organizational ambidexterity: Past, present, and future", Academy of Management Perspectives (27:4), 2013, pp. 324-338.

[27] A. Ordanini, G. Rubera, and M. Sala, "Integrating functional knowledge and embedding learning in new product launches: How project forms helped EMI music", Long Range Planning (41:1), 2008, pp. 17-32.

[28] R.A. Burgelman, "Strategy as vector and the inertia of coevolutionary lock-in", Administrative Science Quarterly (47:2), 2002, pp. 325-357.

[29] W.K. Smith, A. Binns, and M.L. Tushman, "Complex business models: Managing strategic paradoxes simultaneously", Long Range Planning (43:2/3), 2010, pp. $448-461$

[30] M.J. Benner and M.L. Tushman, "Exploitation, exploration, and process management: The productivity dilemma revisited", Academy of Management Review (28:2), 2003, pp. 238-256.

[31] D. Vorhies, L. Orr, and V. Bush, "Improving customerfocused marketing capabilities and firm financial performance via marketing exploration and exploitation", 
Journal of the Academy of Marketing Science (39:5), 2011, pp. 736-756.

[32] H.I. Ansoff, "Strategies for diversification", Harvard Business Review (35:5), 1957, pp. 113-124.

[33] S.A. Fernhaber and P.C. Patel, "How do young firms manage product portfolio complexity? The role of absorptive capacity and ambidexterity", Strategic Management Journal (33:13), 2012, pp. 1516-1539.

[34] J.J.P. Jansen, M.P. Tempelaar, F.A.J. Van Den Bosch, and H.W. Volberda, "Structural differentiation and ambidexterity: The mediating role of integration mechanisms", Organization Science (20:4), 2009, pp. 797811 .

[35] B.A. Aubert, R. Kishore, and A. Iriyama, "Exploring and managing the 'innovation through outsourcing' paradox", Journal of Strategic Information Systems (24), 2015, pp. 255-269.

[36] O. Schilke, "On the contingent value of dynamic capabilities for competitive advantage: The nonlinear moderating effect of environmental dynamism", Strategic Management Journal (35:2), 2014, pp. 179-203.

[37] H. Romijn and M. Albaladejo, "Determinants of innovation capability in small electronics and software firms in southeast England", Research Policy (31:7), 2002, pp. 1053-1067.

[38] X.F. Ma, X.T. Yao, and Y.M. Xi, "How do interorganizational and interpersonal networks affect a firm's strategic adaptive capability in a transition economy?", Journal of Business Research (62:11), 2009, pp. 1087-1095.

[39] D.A. Levinthal and J.G. March, "The myopia of learning”, Strategic Management Journal (14), 1993, pp. 95112

[40] J.J.P. Jansen, Z. Simsek, and Q. Cao, “Ambidexterity and performance in multiunit contexts: Cross-level moderating effects of structural and resource attributes", Strategic Management Journal (33:11), 2012, pp. 1286-1303.

[41] K. Kyriakopoulos and C. Moorman, "Tradeoffs in marketing exploitation and exploration strategies: The overlooked role of market orientation", International Journal of Research in Marketing (21:3), 2004, pp. 219-240.

[42] C.M. Banbury and W. Mitchell, "The effect of introducing important incremental innovations on market share and business survival", Strategic Management Journal (16:S1), 1995, pp. 161-182.

[43] H.-J. Cho and V. Pucik, "Relationship between innovativeness, quality, growth, profitability, and market value", Strategic Management Journal (26:6), 2005, pp. 555575 .
[44] J.K. Han, N. Kim, and R.K. Srivastava, "Market orientation and organizational performance: Is innovation a missing link?", Journal of Marketing (62:4), 1988, pp. 30-45.

[45] J.T. Delaney and M.A. Huselid, "The impact of human resource management practices on perceptions of organizational performance", Academy of Management Journal (39:4), 1996, pp. 949-969.

[46] B.J. Jaworski and A.K. Kohli, "Market orientation: Antecedents and consequences", Journal of Marketing (57:3), 1993, pp. 53-70.

[47] H. Gatignon and J.-M. Xuereb, "Strategic orientation of the firm and new product performance", Journal of Marketing Research (34:1), 1997, pp. 77-90.

[48] K.Z. Zhou, C.K. Yim, and D.K. Tse, "The effects of strategic orientations on technology- and market-based breakthrough innovations", Journal of Marketing (69:2), 2005 , pp. 42-60.

[49] R.P. Bagozzi and Y. Yi, "On the evaluation of structural equation models", Journal of the Academy of Marketing Science (16:1), 1988, pp. 74-94.

[50] J.C. Anderson and D.W. Gerbing, "Structural equation modeling in practice: A review and recommended two-step approach", Psychological Bulletin (103:3), 1988, pp. 411423

[51] C. Fornell and D.F. Larcker, "Evaluating structural equation models with unobservable variables and measurement error", Journal of Marketing Research (18:1), 1981, pp. 39-50.

[52] L.K. Muthén and B.O. Muthén, Mplus user's guide, Seventh Edition, Los Angeles: Muthén \& Muthén, 2012.

[53] J. Algina and B.C. Moulder, "A note on estimating the Jöreskog-Yang model for latent interactions using LISREL 8.3", Structural Equation Modeling (8:1), 2001, pp. 40-52.

[54] H.W. Marsh, Z. Wen, and K.T. Hau, "Structural equation models of latent interactions: Evaluation of alternative estimation strategies and indicator construction", Psychological Methods (9:3), 2004, pp. 275-300.

[55] M.K. Lindell and D.J. Whitney, "Accounting for common method variance in cross-sectional research designs", Journal of Applied Psychology (86:1), 2001, pp. 114-121.

[56] S. Mithas and R.T. Rust, "How information technology strategy and investments influence firm performance: Conjecture and empirical evidence", MIS Quarterly (40:1), 2016, pp. 223-245. 